Article

\title{
Alkaloid-Rich Crude Extracts, Fractions and Piperamide Alkaloids of Piper guineense Possess Promising Antibacterial Effects
}

\author{
Eunice Ego Mgbeahuruike ${ }^{1, *}$, Pia Fyhrquist ${ }^{1}$, Heikki Vuorela ${ }^{1}$, Riitta Julkunen-Tiitto ${ }^{2}$ and \\ Yvonne Holm ${ }^{1}$ \\ 1 Division of Pharmaceutical Biosciences, Faculty of Pharmacy, University of Helsinki, P.O. Box 56, \\ FI-00014 Helsinki, Finland; Pia.fyhrquist@helsinki.fi (P.F.); Heikki.vuorela@helsinki.fi (H.V.); \\ Yvonne.holm@helsinki.fi (Y.H.) \\ 2 Natural Product Research Laboratory, Department of Environmental and Biological Sciences, University of \\ Eastern Finland, 80101 Joensuu, Finland; Riitta.julkunen-tiitto@uef.fi \\ * Correspondence: eunice.mgbeahuruike@helsinki.fi; Tel.: +3-584-4239-9653
}

Received: 6 October 2018; Accepted: 6 November 2018; Published: 9 November 2018

\begin{abstract}
Piper guineense is a food and medicinal plant commonly used to treat infectious diseases in West-African traditional medicine. In a bid to identify new antibacterial compounds due to bacterial resistance to antibiotics, twelve extracts of $P$. guineense fruits and leaves, obtained by sequential extraction, as well as the piperine and piperlongumine commercial compounds were evaluated for antibacterial activity against human pathogenic bacteria. HPLC-DAD and UHPLC/Q-TOF MS analysis were conducted to characterize and identify the compounds present in the extracts with promising antibacterial activity. The extracts, with the exception of the hot water decoctions and macerations, contained piperamide alkaloids as their main constituents. Piperine, dihydropiperine, piperylin, dihydropiperylin or piperlonguminine, dihydropiperlonguminine, wisanine, dihydrowisanine and derivatives of piperine and piperidine were identified in a hexane extract of the leaf. In addition, some new piperamide alkaloids were identified, such as a piperine and a piperidine alkaloid derivative and two unknown piperamide alkaloids. To the best of our knowledge, there are no piperamides reported in the literature with similar UV $\lambda$ absorption maxima and masses. A piperamide alkaloid-rich hexane leaf extract recorded the lowest MIC of $19 \mu \mathrm{g} / \mathrm{mL}$ against Sarcina sp. and gave promising growth inhibitory effects against $S$. aureus and E. aerogenes as well, inhibiting the growth of both bacteria with a MIC of $78 \mu \mathrm{g} / \mathrm{mL}$. Moreover, this is the first report of the antibacterial activity of P. guineense extracts against Sarcina sp. and E. aerogenes. Marked growth inhibition was also obtained for chloroform extracts of the leaves and fruits against $P$. aeruginosa with a MIC value of $78 \mu \mathrm{g} / \mathrm{mL}$. Piperine and piperlongumine were active against E. aerogenes, S. aureus, E. coli, S. enterica, P. mirabilis and B. cereus with MIC values ranging from 39-1250 $\mu \mathrm{g} / \mathrm{mL}$. Notably, the water extracts, which were almost devoid of piperamide alkaloids, were not active against the bacterial strains. Our results demonstrate that $P$. guineense contains antibacterial alkaloids that could be relevant for the discovery of new natural antibiotics.
\end{abstract}

Keywords: Piperamides; antibacterial; Piper guineense; piperine; piperlongumine

\section{Introduction}

Bacterial infections, resulting from bacterial contamination of food and water as well as from wound and post-operative infections are currently a menace in Sub-Saharan Africa [1]. The continuous increase in microbial resistance due to the gross misuse of antibiotics has led to a decline in the effectivity of antibiotic treatments. Consequently, there is a constant need for new antibacterial drugs 
with good efficacy, few and mild adverse effects and low cost. The increasing microbial resistance to antibiotics has led to the search for new antibacterial agents from medicinal plants [2] and medicinal plants such as Piper guineense and Xylopia aethiopica, which are used in the treatment of bacterial infections in West African traditional medicine, could be good sources for these compounds. Based on numerous pharmacological studies, there is growing interest in medicinal plants as sources of antibacterial agents and adjuvants [3,4]. It has been established that plant-derived compounds and plant extracts are potential sources for new antibacterial drugs against multi-drug-resistant (MDR) pathogens [3,5]. In many African countries, bacterial infections are among the main causes of diseases that affect the population and they often lead to life-threatening complications and can frequently result in death. Due to the prevalence of these bacterial infections and lack of adequate modern health facilities, low income earners in remote communities often practice self-medication, using herbal formulations for the treatment of bacterial infections. Moreover, a greater number of them seek medications from traditional medical practitioners (TMP), due to the high cost of treatment associated with the few modern health facilities [6]. The availability and accessibility of numerous medicinal plants in Africa has led to the use of plant extracts as herbal remedies for infectious diseases.

Piper guineense Schumach \& Thonn, also known as African guinea pepper or African black pepper, is a medicinal plant that has a wide application in traditional medicine and is therefore of great ethnobotanical interest [7-9]. It is a perennial climbing vine reaching heights of $20 \mathrm{~m}$. African black pepper has a pungent aroma and the fruits, leaves and roots are used for the preparation of herbal remedies for the treatment of infectious diseases [10,11]. In recent studies, P. guineense has been shown to be one of the most valuable spices with numerous health benefits [12]. In an ethnopharmacological survey conducted by Ajibesin et al. [13], P. guineense was found to be one of the major medicinal plants used for the treatment of various sexually transmitted diseases. Phytochemical studies have revealed that alkaloids, some of which could be novel drug compounds or scaffolds, are the main antimicrobial compounds present in P. guineense [14-17].

The aim of this study was to screen extracts of various polarities of $P$. guineense fruits and leaves and piperine and piperlongumine commercial compounds for antibacterial activity against significant human pathogenic bacteria including five Gram-negative and three Gram-positive bacteria. An agar well diffusion and a microdilution method were used for the screenings [18]. Moreover, selected extracts with promising antibacterial activities were investigated for their phytochemical composition using HPLC-DAD and UHPLC/Q-TOF MS in search of antibacterial extracts and compounds. Although P. guineense crude extracts have been previously reported to exhibit antibacterial properties [19-23], to the best of our knowledge, this is the first report on the antibacterial effects of $P$. guineense extracts of various polarities obtained by sequential extraction, supporting its ethnopharmacological uses. The present study is also the first report on the antibacterial evaluation of $P$. guineense extracts against Enterobacter aerogenes and Sarcina sp. Alsoverylittle is known about the antibacterial activity of the commercial piperamide compounds piperlongumine and piperine against these pathogenic bacterial strains. Since piperine and its related derivatives and synthetic piperine analogues are currently paving way as therapeutic agents for multiple human infectious diseases [24,25], there is a need to screen related piperamides against pathogenic multidrug-resistant bacteria such as Pseudomonas aeruginosa, Escherichia coli and Staphylococcus aureus.

\section{Results}

\subsection{Antibacterial Activity}

The results for the antibacterial activity of $P$. guineense extracts of various polarities are shown in Tables 1 and 2. The bacteria used for the screenings were model human pathogenic bacteria that are of clinical importance. 
Table 1. Antibacterial effects of extracts of P. guineense, piperine and piperlongumine against Gram-negative bacteria. Results obtained with the agar diffusion method. Activity index (AI) describes the activity of the extracts and compounds in relation to tetracycline.

\begin{tabular}{|c|c|c|c|c|c|c|c|c|c|c|}
\hline Extracts/Antibiotics & E. aerogenes & AI Tet. & E. coli & AI Tet. & P. aeruginosa & AI Tet. & S. enterica & AI Tet. & P. mirabilis & AI Tet. \\
\hline $\mathrm{PSMeOH}$ & $49.7 \pm 0.33$ & 1.10 & $20.7 \pm 0.33$ & 0.42 & $16.3 \pm 0.33$ & 0.29 & $13.3 \pm 0.67$ & 0.31 & $13.7 \pm 0.72$ & 0.34 \\
\hline $\mathrm{PSCHCL}_{3}$ & $11.3 \pm 0.33$ & 0.25 & $20.3 \pm 0.33$ & 0.41 & $17.7 \pm 0.33$ & 0.32 & $18.0 \pm 0.0$ & 0.32 & $11.3 \pm 0.33$ & 0.28 \\
\hline PSHex & $34.7 \pm 0.33$ & 0.76 & NA & NA & NA & NA & $12.7 \pm 0.71$ & 0.23 & $11.7 \pm 0.33$ & 0.29 \\
\hline $\mathrm{PSH}_{2} \mathrm{O}$ * & NA & NA & NA & NA & NA & $\mathrm{NA}$ & NA & NA & NA & NA \\
\hline $\mathrm{PSHH}_{2} \mathrm{O}$ & NA & NA & NA & NA & NA & NA & NA & NA & NA & NA \\
\hline PSEthanol & $30.2 \pm 0.17$ & 0.67 & $19.8 \pm 0.24$ & 0.40 & NT & NT & $21.7 \pm 0.33$ & 0.39 & $16.3 \pm 0.32$ & 0.40 \\
\hline $\mathrm{PLMeOH}$ & $29.3 \pm 0.33$ & 0.65 & $11.3 \pm 0.33$ & 0.23 & $15.3 \pm 0.33$ & 0.28 & $12.0 \pm 0.00$ & 0.22 & $11.3 \pm 0.31$ & 0.28 \\
\hline $\mathrm{PLCHCL}_{3}$ & $11.3 \pm 0.33$ & 0.25 & $20.3 \pm 0.33$ & 0.41 & $21.3 \pm 0.33$ & 0.38 & $11.7 \pm 0.33$ & 0.21 & $10.7 \pm 0.23$ & 0.26 \\
\hline PLHex & $17.8 \pm 0.17$ & 0.39 & NA & NA & NA & NA & NA & NA & $11.7 \pm 0.33$ & 0.29 \\
\hline $\mathrm{PLH}_{2} \mathrm{O}$ * & NA & NA & NA & NA & NA & NA & NA & NA & NA & NA \\
\hline $\mathrm{PLHH}_{2} \mathrm{O}$ & NA & NA & NA & NA & NA & NA & NA & NA & NA & NA \\
\hline PLEthanol & $25.0 \pm 0.00$ & 0.55 & $16.3 \pm 0.33$ & 0.33 & NT & NT & $16.2 \pm 0.24$ & 0.29 & $13.8 \pm 0.2$ & 0.34 \\
\hline Piperine & $18.7 \pm 0.67$ & 0.41 & $22.3 \pm 0.32$ & 0.45 & $15.7 \pm 0.73$ & 0.28 & $14.7 \pm 0.32$ & 0.26 & $16.0 \pm 0.63$ & 0.39 \\
\hline Piperlongumine & $12.7 \pm 0.65$ & 0.28 & $20.0 \pm 0.33$ & 0.40 & $13.3 \pm 0.32$ & 0.24 & $11.3 \pm 0.33$ & 0.20 & NA & NA \\
\hline Rifampicin & $38.0 \pm 0.00$ & 0.84 & $40.3 \pm 0.34$ & 0.81 & $45.3 \pm 0.33$ & 0.81 & $39.3 \pm 0.33$ & 0.71 & $34.3 \pm 0.33$ & 0.8 \\
\hline Tetracycline & $45.3 \pm 0.67$ & 1.00 & $49.7 \pm 0.33$ & 1.00 & $55.7 \pm 0.33$ & 1.00 & $55.7 \pm 0.33$ & 1.00 & $40.7 \pm 0.74$ & 1.00 \\
\hline
\end{tabular}

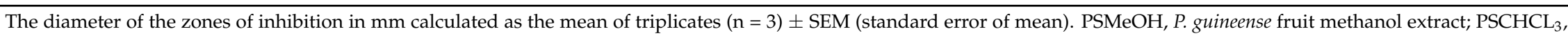
$P$. guineense fruit chloroform extract; $\mathrm{PSHex}, P$. guineense fruit hexane extract; $\mathrm{PSH}_{2} \mathrm{O} *$, P. guineense fruit cold water maceration; $\mathrm{PSHH} \mathrm{H}_{2} \mathrm{O}, P$. guineense fruit hot water decoction; $\mathrm{PSE}$ thanol, P. guineense fruit ethanol extract; $\mathrm{PLMeOH}, P$. guineense leaf methanol extract; $\mathrm{PLCHCL}_{3}$, P. guineense leaf chloroform extract; PLHex, P. guineense leaf hexane extract; $\mathrm{PLH} \mathrm{H}_{2} \mathrm{O} *, P$. guineense leaf cold water maceration; $\mathrm{PLHH}_{2} \mathrm{O}$, P. guineense leaf hot water decoction; PLEthanol, P. guineense leaf ethanol extract; AI Tet., activity index in relation to tetracycline; NA, not active and NT, not tested. 
Table 2. Antibacterial effects of extracts of Piper guineense, piperine and piperlongumine against Gram-positive bacteria. Results obtained with the agar diffusion method. Activity index (AI) describes the activity of the extracts and compounds in relation to tetracycline.

\begin{tabular}{ccccccc}
\hline Extracts/Antibiotics & Sarcina sp. & AI Tet. & S. aureus & AI Tet. & B. cereus & AI Tet. \\
\hline PSMeOH & $29.83 \pm 0.17$ & 0.72 & $15.7 \pm 0.33$ & 0.32 & $23.7 \pm 0.32$ & 0.44 \\
PSCHCL $_{3}$ & $31.67 \pm 0.33$ & 0.76 & $17.3 \pm 0.67$ & 0.35 & $15.7 \pm 0.33$ & 0.29 \\
$\mathrm{PSHex} \mathrm{PSH}_{2} \mathrm{O}$ & $37.67 \pm 0.33$ & 0.90 & $17.3 \pm 0.33$ & 0.35 & $19.7 \pm 0.33$ & 0.36 \\
$\mathrm{PSHH}_{2} \mathrm{O}$ & $10.67 \pm 0.33$ & 0.26 & $\mathrm{NA}$ & $\mathrm{NA}$ & $\mathrm{NA}$ & $\mathrm{NA}$ \\
$\mathrm{PSEthanol}^{*}$ & $17.67 \pm 0.33$ & 0.42 & $\mathrm{NA}$ & $\mathrm{NA}$ & $\mathrm{NA}$ & $\mathrm{NA}$ \\
$\mathrm{PLMeOH}$ & $28.33 \pm 0.33$ & 0.68 & $22.67 \pm 0.33$ & 0.46 & $24.5 \pm 0.33$ & 0.45 \\
$\mathrm{PLCHCL}_{3}$ & $26.17 \pm 0.17$ & 0.63 & $14.7 \pm 0.33$ & 0.30 & $29.3 \pm 0.33$ & 0.54 \\
$\mathrm{PLHex}$ & $33.67 \pm 0.33$ & 0.62 & $16.7 \pm 0.67$ & 0.34 & $15.3 \pm 0.32$ & 0.28 \\
$\mathrm{PLH}_{2} \mathrm{O}{ }^{*}$ & $10.67 \pm 0.33$ & 0.81 & $15.0 \pm 0.00$ & 0.30 & $24.7 \pm 0.31$ & 0.45 \\
$\mathrm{PLHH}_{2} \mathrm{O}$ & $14.33 \pm 0.33$ & 0.34 & $\mathrm{NA}$ & $\mathrm{NA}$ & $\mathrm{NA}$ & $\mathrm{NA}$ \\
$\mathrm{PLEthanol}$ & $25.17 \pm 0.17$ & 0.60 & $17.5 \pm 0.29$ & 0.35 & $28.2 \pm 0.24$ & 0.52 \\
Piperine & $27.67 \pm 0.33$ & 0.66 & $18.3 \pm 0.33$ & 0.37 & $12.7 \pm 0.33$ & 0.23 \\
Piperlongumine & $23.67 \pm 0.33$ & 0.57 & $15.3 \pm 0.33$ & 0.31 & $15.7 \pm 0.3$ & 0.29 \\
Rifampicin & $39.33 \pm 0.33$ & 0.94 & $48.3 \pm 0.33$ & 0.98 & $50.7 \pm 0.33$ & 0.93 \\
Tetracycline & $41.67 \pm 0.33$ & 1.00 & $49.3 \pm 0.33$ & 1.00 & $54.3 \pm 0.32$ & 1.00 \\
\hline
\end{tabular}

The diameter of the zones of inhibition in mm calculated as the mean of triplicates $(n=3) \pm$ SEM (standard error of mean). For the key to other abbreviations, see Table $1 . \mathrm{PSH}_{2} \mathrm{O}$, P. guineense fruit cold water maceration and $\mathrm{PLH}_{2} \mathrm{O}$ *, P. guineense leaf cold water maceration.

\subsubsection{Antibacterial Activity of P. guineense Extracts against Pseudomonas aeruginosa}

Themethanol and chloroform extracts of the leaves and fruits of $P$ guineense were effective against Pseudomonas aeruginosa with inhibition zones ranging from 15.3-21.3 mm (Table 1). In agreement with our results for the fruits, Eruteya et al. [26], reported that a methanol extract of $P$. guineense fruits gave the best growth inhibitory activity against $P$. aeruginosa. However, in our study, a chloroform leaf extract gave the largest inhibition zone of $21.3 \mathrm{~mm}$, whereas a methanol leaf extract gave a significantly smaller IZ of $15.3 \mathrm{~mm}$, which could be due to the higher concentrations of other piperamide alkaloids relative to piperine in the chloroform extract compared to the methanol extract of the leaves. Moreover, the minimum inhibitory concentrations (MIC) of the chloroform extracts were $78 \mu \mathrm{g} / \mathrm{mL}$ for both fruits and leaf, while the MIC of the methanol extracts were $1250 \mu \mathrm{g} / \mathrm{mL}$ for both the fruits and leaves and these results correlated well with the agar diffusion results for these extracts (Table 3). Our result demonstrates that chloroform extracts of the leaves of $P$. guineense containa high variety and concentration of piperamide alkaloids and other non-polar compounds that may be explored as antibacterial agents, alone and in combinations with antibiotics, for multidrug-resistant bacteria. In addition to the extracts, we studied the antibacterial effects of some piperamide alkaloids, such as piperine, which we have found to be present in high concentrations in P. guineense leaves (Figure 1) and piperlongumine, which is known in many species of Piper, although we did not find it in the leaves of $P$. guineense. Piperine gave moderate activity against $P$. aeruginosa with an inhibition zone of $13.3 \mathrm{~mm}$ and MIC of $156 \mu \mathrm{g} / \mathrm{mL}$ and thus, may not be the only bioactive compound responsible for the good growth inhibitory effects of the leaf chloroform extract of P. guineense. Thus, some other piperamide alkaloids in the leaf extract of $P$. guineense are suggested to be even more effective and should be tested alone for their growth inhibitory effects against $P$. aeruginosa. Piperlongumine was more effective against $P$. aeruginosa in terms of the sizes of its inhibition zones of $(15.7 \mathrm{~mm})$ but gave a higher MIC value $(312 \mu \mathrm{g} / \mathrm{mL})$ than piperine. However, it is interesting to note that the hexane and water extracts of both leaves and fruits of $P$. guineense were not active against Pseudomonas aeruginosa. This result might be explained by the absence of piperamide alkaloids in the water extracts. Moreover, the inactivity of the hexane extracts could possibly be reflected to their smaller quantity of piperamides when compared to the chloroform extracts. Our results demonstrate that P. guineense could be a source 
of new antibacterial agents or adjuvants that could be relevant for the treatment of infections associated with Pseudomonas aeruginosa.

Table 3. Minimum inhibitory concentration and minimum bactericidal concentrations (MIC and MBC) in $\mu \mathrm{g} / \mathrm{mL}$ of fruit and leaf extracts of Piper guineense and the alkaloids piperine and piperlongumine.

\begin{tabular}{|c|c|c|c|c|c|c|c|c|}
\hline $\begin{array}{l}\text { Plant Extracts and } \\
\text { Antibiotics }\end{array}$ & Sarcina sp. & S. aureus & B. cereus & P. mirabilis & E. aerogenes & E. coli & P. aeruginosa & S. enterica \\
\hline \multicolumn{9}{|l|}{$\mathrm{PSMeOH}$} \\
\hline MIC & 39 & 625 & 78 & 1250 & 39 & 1250 & 1250 & 625 \\
\hline MBC & 78 & 1250 & 156 & 2500 & 78 & 2500 & 2500 & 1250 \\
\hline \multicolumn{9}{|l|}{$\mathrm{PSCHCL}_{3}$} \\
\hline MIC & 156 & 156 & 625 & 2500 & 312 & 312 & 78 & 78 \\
\hline MBC & 312 & 312 & 1250 & NT & 625 & 625 & 156 & 156 \\
\hline \multicolumn{9}{|l|}{ PSHex } \\
\hline MIC & 39 & 78 & 625 & 2500 & 39 & NA & NA & 2500 \\
\hline MBC & 78 & 156 & 1250 & NT & 78 & NA & NA & NT \\
\hline \multicolumn{9}{|l|}{ PSEthanol } \\
\hline MIC & 39 & 78 & 39 & 78 & 78 & 156 & NT & 78 \\
\hline MBC & 78 & 156 & 78 & 156 & 156 & 312 & NT & 156 \\
\hline \multicolumn{9}{|l|}{ PLMeOH } \\
\hline MIC & 39 & 312 & 78 & 1250 & 39 & 1250 & 1250 & 625 \\
\hline MBC & 78 & 625 & 156 & 2500 & 78 & 2500 & 2500 & 1250 \\
\hline \multicolumn{9}{|l|}{$\mathrm{PLCHC}_{3}$} \\
\hline MIC & 78 & 625 & 625 & 2500 & 312 & 312 & 78 & 78 \\
\hline $\mathrm{MBC}$ & 156 & 1250 & 1250 & NT & 625 & 625 & 156 & 156 \\
\hline \multicolumn{9}{|l|}{ PLHex } \\
\hline MIC & 19 & 78 & 625 & 1250 & 78 & NA & NA & NT \\
\hline MBC & 39 & 156 & 1250 & 2500 & 156 & NA & NA & NT \\
\hline \multicolumn{9}{|l|}{ PLEthanol } \\
\hline MIC & 39 & 78 & 39 & 78 & 78 & 312 & NT & 78 \\
\hline MBC & 78 & 156 & 78 & 156 & 156 & 625 & NT & 156 \\
\hline \multicolumn{9}{|l|}{ Piperine } \\
\hline MIC & 19 & 39 & 625 & 78 & 39 & 19 & 156 & 78 \\
\hline MBC & 39 & 78 & 1250 & 156 & 78 & 39 & 312 & 156 \\
\hline \multicolumn{9}{|l|}{ Piperlongumine } \\
\hline MIC & 9.7 & 156 & 78 & NA & 156 & 39 & 312 & 625 \\
\hline MBC & 19 & 312 & 156 & NA & 312 & 78 & 625 & 1250 \\
\hline \multicolumn{9}{|l|}{ Tetracycline } \\
\hline MIC & 0.48 & 0.97 & 0.48 & 1.95 & 0.48 & 0.48 & 0.48 & 0.97 \\
\hline \multicolumn{9}{|l|}{ Rifampicin } \\
\hline MIC & 0.97 & 0.97 & 0.48 & 0.97 & 0.48 & 0.48 & 0.48 & 0.48 \\
\hline
\end{tabular}

For the key to other abbreviations, see Table 1 . The extracts with marked MIC values are in bold.

\subsubsection{Antibacterial Activity of P. guineense Extracts against Bacillus Cereus}

Extracts from P. guineense were susceptible to B. cereus with inhibition zones ranging from 15.3-29.3 mm (Table 2). The largest zones of inhibition $(29.3 \mathrm{~mm}$ and $28.2 \mathrm{~mm}$ ) were observed with the methanol and ethanol extracts of the leaves and this result correlated well with the MIC values for these extracts, which were found to be $78 \mu \mathrm{g} / \mathrm{mL}$ and $39 \mu \mathrm{g} / \mathrm{mL}$, respectively. The inhibition zones for the methanol and ethanol extracts of the fruits were $23.7 \mathrm{~mm}$ and $24.5 \mathrm{~mm}$, respectively and the MIC values of these extracts were $78 \mu \mathrm{g} / \mathrm{mL}$ and $39 \mu \mathrm{g} / \mathrm{mL}$. Based on the result obtained with this bacterium, it is interesting to note that the leaf extracts were more active than the fruit extracts. It could be possible that the leaf contains more antibacterial compounds that could inhibit the growth of this particular bacterium. Moreover, we found that the hexane and chloroform extracts were active against $B$. cereus but in contrast the water extracts were not active. This result demonstrates that the piperamide alkaloids present both in the methanol and ethanol extracts, as well as in the hexane extract of the leaf (Figure 1) is important for the growth inhibitory effects of these extracts against B. cereus. Thus, the inactivity of the water extract could be related to the absence of piperamide alkaloids in this extract. 
Our results could justify the use of $P$. guineense ethanol extracts asherbal remedy for the treatment of diarrhoea related to foodborne diseases.

\subsubsection{Antibacterial Activity of P. guineense Extracts against Staphylococcus Aureus}

P. guineense extracts and pure compounds were active against $S$. aureus with inhibition zones ranging from 14.7-22.67 mm. In this study, the largest inhibition zone of $22.67 \mathrm{~mm}$ was observed with an ethanol extract of the fruits, followed by a leaf ethanol extract and chloroform and hexane extracts of the fruits (Table 2). For the ethanol extract of the fruits, our agar diffusion results correlated well with the MIC resultof $78 \mu \mathrm{g} / \mathrm{mL}$ (Table 3). However, this same MIC of $78 \mu \mathrm{g} / \mathrm{mL}$ could also be recorded for the ethanol extract of the leaves as well as the fruit hexane and chloroform extracts, even though these extracts produced smaller inhibition zones than the leaf ethanol extract. In contrast to the other extracts we found that the water extracts of both the leaves and fruits showed no inhibition. Thus, our result suggests that $P$. guineense should not be used as water extracts for the treatment of bacterial infections but rather the fruits or leaves should be soaked with alcohol. When compared to the extracts of $P$. guineense, we found that the piperamide alkaloids, present in the extracts, were not more growth inhibitory. Piperine was more active than piperlongumine, giving an inhibition zone of $18.3 \mathrm{~mm}$ and a MIC of $78 \mu \mathrm{g} / \mathrm{mL}$, compared to $15.3 \mathrm{~mm}$ and $156 \mu \mathrm{g} / \mathrm{mL}$ for piperlongumine. This result indicates that piperine is one of the piperamide alkaloids in the ethanol, methanol, chloroform and hexane extracts of $P$. guineense which could be growth inhibitory against $S$. aureus. Our phytochemical profiling of the extracts using HPLC-DAD and UHPLC/QTOF-MS shows that $P$. guineense leaves contain a high variety of piperamide alkaloid derivatives which could all be critical for the antibacterial effects of these extracts (Table 4, Figure 2). Our result correlates with the previous report that piperlongumine has moderate activity against $S$. aureus [27]. Moreover, in agreement with our results, previous reports have also shown that the water extracts of $P$. guineense are usually less effective when compared to the methanol, ethanol and hexane extracts [23]. Our results on the antibacterial activity of the extracts of P. guineense against Staphylococcus aureus justify the use of alcohol extracts and soups containing this plant for the treatment of common foodborne and other infections caused by this bacterium.

\subsubsection{Antibacterial Activity of P. guineense Extracts against Sarcina sp.}

Sarcina sp. was the most sensitive bacterium to extracts of P. guineense. The methanol, ethanol, chloroform and hexane extracts of $P$. guineense showed promising growth inhibitory activity with MIC values between 19-39 $\mu \mathrm{g} / \mathrm{mL}$ and inhibition zones ranging from 25.67-37.67 mm (Table 2). The largest inhibition zones were observed with hexane fruit and leaf extracts, showing remarkable zones of inhibition of 37.67 and $33.67 \mathrm{~mm}$, respectively. Accordingly, the hexane leaf extract also gave a low MIC of $19 \mu \mathrm{g} / \mathrm{mL}$ and was thus as effective as piperine which gave an identical MIC value (Table 3). The antibacterial activity of the hexane leaf extract and the other effective extracts can be attributed to the occurrence of piperine and other piperamide alkaloids as the main constituents in these extracts (Table 4, Figure 1). To the best of our knowledge, this is the first report on the growth inhibitory effects of P. guineense extracts on Sarcina sp. Sarcina sp. is an anaerobic Gram-positive bacterium belonging to the family Clostridiaceae [28]. Sarcina has mainly been characterized as the causative agent of abomasal bloat leading to the death of livestock [29]. There is still a debate whether Sarcina is pathogenic to humans, although a number of cases of human disease, including gastric perforation, emphysematous gastritis and gastric ulcer have been associated with Sarcina [28-30]. Our result demonstrates that the hexane extracts of both P. guineense fruits and leaves contain antibacterial piperamide alkaloids, which could be used as therapeutic agents in the treatment of Sarcina infections. The findings justify the traditional use of $P$. guineense alcoholextracts for the treatment of stomach related problems, including gastric ulcers. 
Table 4. HPLC-DAD and UHPLC/QTOF-MS data of alkaloids from a Piper guineense leaf hexane extract.

\begin{tabular}{|c|c|c|c|c|c|c|c|c|c|}
\hline $\begin{array}{l}\text { Piper guineense Peak Number and Name } \\
\text { of Compound }\end{array}$ & $\begin{array}{l}\text { Molecular } \\
\text { Formula }\end{array}$ & $\begin{array}{c}\text { Rt } \\
\text { HPLC-DAD } \\
\text { (min) }\end{array}$ & $\begin{array}{c}\text { Rt UHPLC } \\
\text { (min) }\end{array}$ & $\begin{array}{c}\text { Measured } \\
\text { Mass }\end{array}$ & $\begin{array}{l}\text { Calculated } \\
\text { Mass }\end{array}$ & {$[\mathrm{M}+1]^{+}$} & Other Ions $\mathrm{m} / \mathrm{z}$ & UV入 Absorption Max. & $\begin{array}{c}\text { Accuracy } \\
\text { (ppm) }\end{array}$ \\
\hline 1. Unknown & & 11,840 & 2842 & 187,0306 * & & 165,0487 & & 214,236 & - \\
\hline 2. Unknown (Ellagitannin?) & & 16,383 & 6173 & 312,1211 * & & 290,1392 & & 210,270 & - \\
\hline 3. Unknown & & 23,461 & 6373 & $390,1516^{*}$ & & 368,1697 & & & - \\
\hline Unknown & & 33,389 & 12,567 & 231,0993 * & & 209,1174 & & $220,238,320,355$ & - \\
\hline 6. Unknown & & 36,456 & 13,267 & 187,0277 & & 165,0458 & 143,$068 ; 111,0420$ & & - \\
\hline 7. Dihydropiperylin or piperlonguminine & $\mathrm{C}_{16} \mathrm{H}_{19} \mathrm{NO}_{3}$ & 36,852 & 12,967 & 296,1250 * & 273.1365 & 274.1431Q & $2(\mathrm{M})^{+}-23: 569,2628$ & $210,235,284$ & $-4,2212$ \\
\hline 7.1. Unknown & & & 13,267 & 187,0277 & & 165,0458 & 143,$068 ; 111,0420$ & & - \\
\hline 8. Piperylin & $\mathrm{C}_{16} \mathrm{H}_{17} \mathrm{NO}_{3}$ & 38,563 & 13,567 & $294,1100 *$ & 271,1208 & $272,1281 Q$ & $2(\mathrm{M})^{+}-23: 565,2321$ & $210,240,308,344$ & $-2,0740$ \\
\hline 9. Piperidine derivative & & 39,226 & 13,783 & $326,1374 *$ & & 304,1555 & $2(\mathrm{M})^{+} 23: 629,2844$ & $210,234,300$ & \\
\hline 10. Dihydropiperlonguminine & $\mathrm{C}_{16} \mathrm{H}_{21} \mathrm{NO}_{3}$ & 41.5 & 14,066 & 298,1337 * & 298,1419 & $276,1518 Q$ & & $210,235,300$ & 27,50 \\
\hline 10b. Piperine derivative & & 39,249 & 14,432 & 324,1211 * & & 302,1392 & $2(\mathrm{M})^{+}-23: 625,2522$ & $210,235,288$ & \\
\hline 11. Unknown piperamide alkaloid & & 40,447 & 15,049 & $358,1528 *$ & & 336,1709 & 143,0682 & $210,220,246,276,355$ & - \\
\hline 11b. Unknown piperamide alkaloid & & 40,447 & 14,832 & 317,1330 * & & 295,1511 & 143,0644 & $210,220,246,276,355$ & - \\
\hline 12. Unknown & & & 16,031 & 247,1612 & & 225,1793 & & & - \\
\hline 13. 4,5-dihydropiperine & $\mathrm{C}_{17} \mathrm{H}_{21} \mathrm{NO}_{3}$ & 42,215 & 15,515 & 310,1417 * & 287,1521 & $288,1598 Q$ & & $210,235,287$ & $-0,6771$ \\
\hline 15. Piperine 1 t & $\mathrm{C}_{17} \mathrm{H}_{19} \mathrm{NO}_{3}$ & 44,809 & 16,647 & $308,1245 *$ & 285,1365 & $286,1426 \mathrm{Q}$ & & $210,240,310,342$ & $-5,7119$ \\
\hline 16. Dihydrowisanine & $\mathrm{C}_{18} \mathrm{H}_{23} \mathrm{NO}_{4}$ & 45,234 & 16,847 & 340,1530 * & 317,1627 & $318,1711 \mathrm{Q}$ & & $210,236,306,340$ & 1,5581 \\
\hline 17. Unknown & & & 17,197 & 247,1659 & & 225,1840 & & & - \\
\hline 18. Wisanine & $\mathrm{C}_{18} \mathrm{H}_{21} \mathrm{NO}_{4}$ & 48,433 & 17,846 & $338,1371 *$ & 315,1471 & $316,1552 Q$ & 247,1662 & $218,253,304,370,372$ & 0,8281 \\
\hline 19. Unknown & & & 18,795 & $243,1299 *$ & & 221,1480 & & & \\
\hline
\end{tabular}

UHPLC/QTOF-MS in positive ion mode was used, ${ }^{*}=\mathrm{M}+23, \mathrm{Q}=\mathrm{M}+1, \mathrm{ppm}=$ mass accuracy in parts per million. All the results with an asterisk are [M +23$]^{+}$results, they are adducts with sodium (mass $=23$ for sodium). Ions for compounds 5 and 14 in HPLC-DAD, Figure 1, were not detected in our UHPLC/QTOF MS system and thus these compounds are left away from Table 4. 


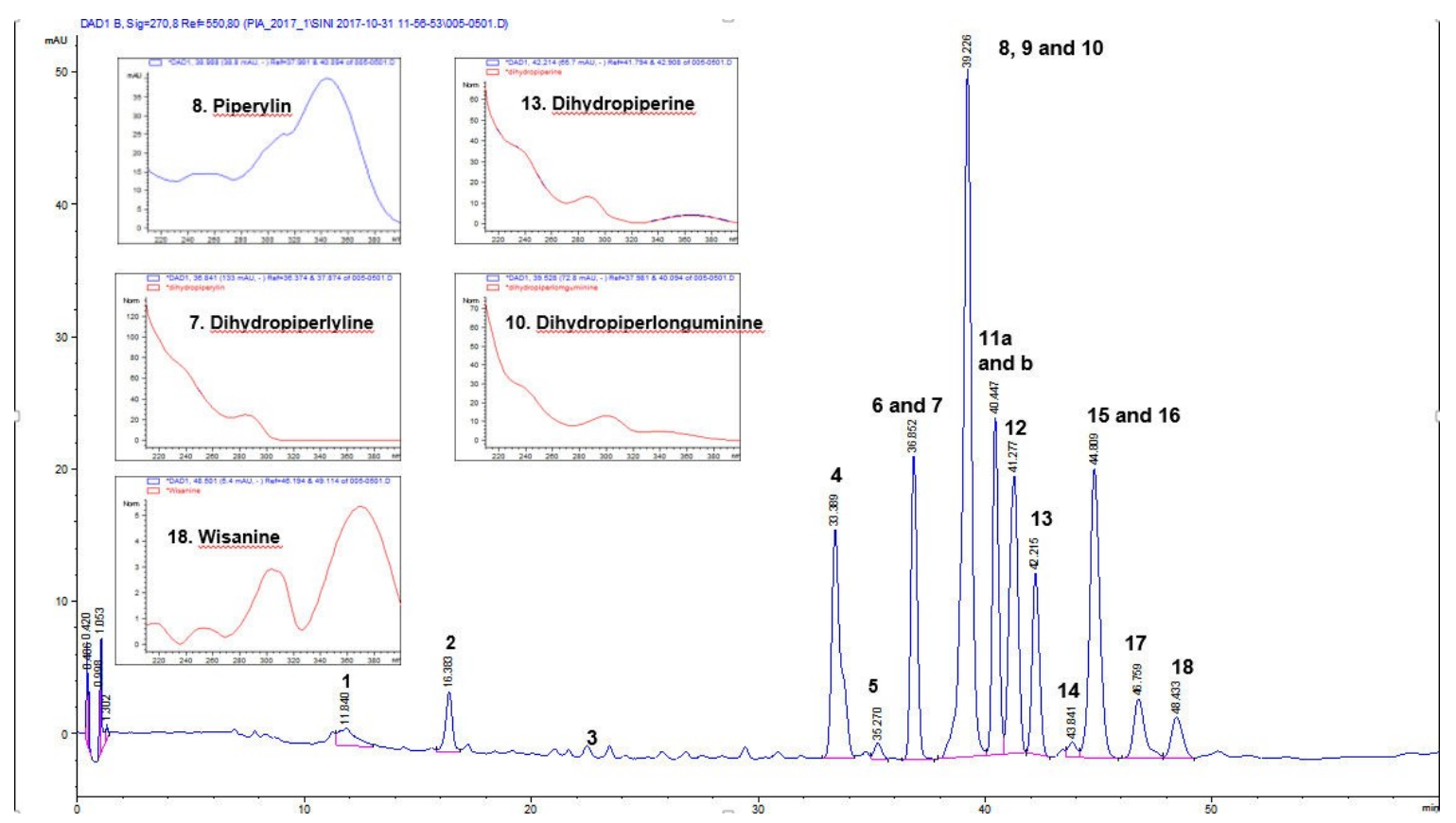

Figure 1. HPLC profile and identified piperamide alkaloids in an antibacterial hexane leaf extract of $P$. guineense at $270 \mathrm{~nm}$. The bioactive compounds identified in this extract are also shown in Table 4 . $\mathrm{UV} \lambda$ absorption maxima of some of the compounds are indicated.

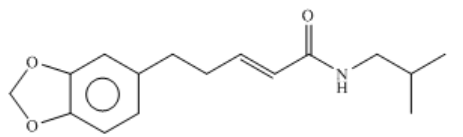

7 Piperlonguminine

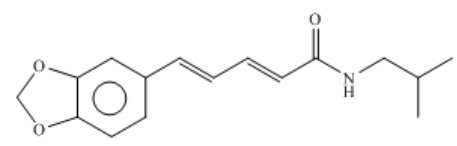

$10 \quad 4,5$-dihydropiperlonguminine

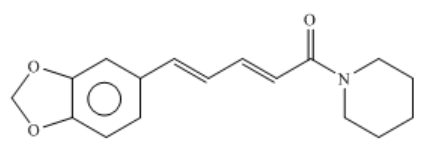

15 Piperine

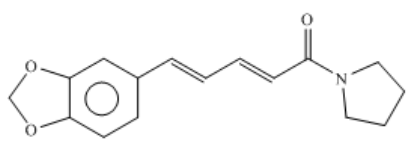

8 Piperylin

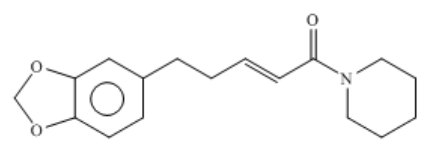

13 4, 5-dihydropiperine

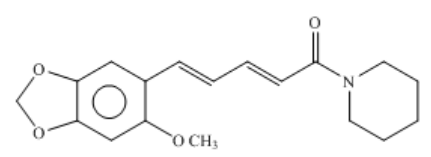

18 Wisanine

Figure 2. Chemical structures of some of the piperamide compounds found in this investigation from the hexane leaf extract of Piper guineense. The compounds are numbered from Table 4.

\subsubsection{Antibacterial Activity of P. guineense Extracts against Proteus Mirabilis}

P. mirabilis was found to be rather resistant against most of the extracts of $P$. guineense. In the primary screening, using agar diffusion, we found that the ethanol and methanol extracts were more active than the chloroform fruit and leaf extracts (Table 1). However, when the microdilution method was used for estimating the MIC values, we found large variations in activity between the extracts demonstrating MIC values between 78 and $2500 \mu \mathrm{g} / \mathrm{mL}$. From these results the ethanol extracts of the fruits and leaves stood out with very low MIC values of $78 \mu \mathrm{g} / \mathrm{mL}$, thus demonstrating that ethanol could be a good solvent for extracting compounds active against $P$. mirabilis (Table 3 ). Contrary to our results, Okeke et al. [31], reported that P. guineense fruit extract is not active against Proteus mirabilis. However, they found activity against Proteus vulgaris. We found that piperine showed significant 
activity against $P$. mirabilis with an inhibition zone of $16.0 \mathrm{~mm}$ and a MIC value of $78 \mu \mathrm{g} / \mathrm{mL}$ and a MBC value of $156 \mu \mathrm{g} / \mathrm{mL}$. Thus, piperine must be responsible for a part of the good antibacterial activity of the ethanol extracts of the fruits and leaves against $P$. mirabilis, since piperine was observed to be present in both extracts according to our preliminary HPLC-DAD data (Figure 1). In contrast to piperine, we found that piperlongumine was not active against $P$. mirabilis. Thus, piperamide alkaloids vary in respect to their antimicrobial activities, even though they would be closely related to their molecular structures. Our results now demonstrate that especially ethanol extracts of P. guineense fruits and leaves could be used for the treatment of urinary tract infections with Proteus mirabilis as the main causative agent.

\subsubsection{Antibacterial Activity of P. guineense Extracts against Enterobacter aerogenes}

We found that a methanol extract of the fruit gave the largest zone of inhibition $(49.7 \mathrm{~mm})$ of all tested extracts against E. aerogenes and the effect was comparable to tetracycline (45.3 mm) (Table 1). Moreover, our MIC value for this extract, $39 \mu \mathrm{g} / \mathrm{mL}$, correlated well with the large inhibition zone (Table 3). The methanol leaf extract showed an inhibition zone of $29.3 \mathrm{~mm}$ and a large inhibition zone of $34.7 \mathrm{~mm}$ was also observed for the hexane-fruit extract, both extracts showing MIC values of $39 \mu \mathrm{g} / \mathrm{mL}$. The hexane leaf extract and ethanol fruit and leaf extracts showed promising inhibitory activity with MIC values of $39 \mu \mathrm{g} / \mathrm{mL}$ and $78 \mu \mathrm{g} / \mathrm{mL}$ respectively. However, the size of the inhibition zone of the hexane leaf extract, $17.8 \mathrm{~mm}$, indicating just slight activity, did not correlate well with the low MIC of $78 \mu \mathrm{g} / \mathrm{mL}$ of this extract (Tables 1 and 3). This result might be due to the hydrophobic piperamide alkaloids present in the leaf hexane extract not diffusing well into the agar and thus producing small zones of inhibition. The chloroform fruit-extract was moderately active with a MIC value of $312 \mu \mathrm{g} / \mathrm{mL}$. To the best of our knowledge, this is the first report on the growth inhibitory activity of the extracts of $P$. guineense against E. aerogenes. Moreover, we found that the piperamidespiperine and piperlongumine were growth inhibitory against E. Aerogenes with inhibition zones of $18.7 \mathrm{~mm}$ and $12.7 \mathrm{~mm}$, respectively, MIC values of $39 \mu \mathrm{g} / \mathrm{mL}$ and $156 \mu \mathrm{g} / \mathrm{mL}$, respectively and MBC values of $78 \mu \mathrm{g} / \mathrm{mL}$ and $312 \mu \mathrm{g} / \mathrm{mL}$, respectively. Thus, piperine which we have found to occur in all extracts, except from water extracts, must be responsible for part of the activity of the methanol, ethanol and hexane extracts of the fruits and leaves against Enterobacter aerogenes. Notably, the water extracts lacking piperamide alkaloids, were devoid of activity. Enterobacter aerogenes is a Gram-negative pathogenic bacterium that is responsible for most hospital-acquired infections [32]. It causes urinary tract infections, lower respiratory tract infections, skin and soft tissue infections.

\subsubsection{Antibacterial Activity of P. guineense Extracts against Escherichia coli}

We recorded the lowest MIC of $156 \mu \mathrm{g} / \mathrm{mL}$ against $E$. coli for an ethanol extract of the leaves of P. guineense, which correlated well with an inhibition zone of $19.8 \mathrm{~mm}$ (Tables 1 and 3). The methanol fruit and leaf extracts of P. guineense also gave large inhibition zones of $20.7 \mathrm{~mm}$ and $20.3 \mathrm{~mm}$, respectively. The chloroform extracts of the fruits and leaves were also effective, both giving an inhibition zone of $20.3 \mathrm{~mm}$. Oppositely to the other extracts, the hexane and water extracts of $P$. guineense were not active against E. coli. For the hexane extract, this result is contradictory since this extract resembles the methanol and ethanol extracts to its piperamide alkaloid content. Therefore, in the methanol and ethanol extracts of the leaves and fruits of $P$. guineense there must be some compounds responsible for the activities which are not present in the hexane extracts. The result further suggests that standardized P. guineense extracts could be used for possible alternative treatment against pathogenic multidrug-resistant E. coli strains. This present study suggests that P. guineense extracts could contain new antimicrobial agents for multidrug-resistant pathogens. Furthermore, we found that the two piperamide pure compounds, piperine and piperlongumine, were effective against E. coli with inhibition zones of $22.3 \mathrm{~mm}$ and $20.0 \mathrm{~mm}$ respectively and MIC values of 19 and $39 \mu \mathrm{g} / \mathrm{mL}$, respectively. This result could indicate that the antibacterial activity of $P$. guineense methanol and ethanol extracts against $E$. coli is partly due to the mentioned piperamide alkaloids. Our results could 
justify the use of $P$. guineense ethanol extracts of the fruits and leaves for the treatment of diarrhoea in African traditional medicine.

\subsubsection{Antibacterial Activity of P. guineense Extracts against Salmonella enterica}

The ethanol fruit extract of $P$. guineense showed the largest zone of inhibition of $21.7 \mathrm{~mm}$ for S. enterica, and MIC and MBC values of $78 \mu \mathrm{g} / \mathrm{mL}$ and $156 \mu \mathrm{g} / \mathrm{mL}$, respectively. The ethanol leaf extract also showed a clear inhibition zone of $16.2 \mathrm{~mm}$ and a MIC of $78 \mu \mathrm{g} / \mathrm{mL}$ (Tables 1 and 3). These results are in accordance with a previous investigation which demonstrates that ethanol extracts of $P$. guineense are growth inhibitory against S. enterica serovar enteritis [33]. However, oppositely to our results, Temitope [33], also found that water extracts of P. guineense inhibit the growth of S. enterica. These differences might be due to Temitope [33] using a different serovar of S. enterica. The result specifically demonstrates that, the more polar ethanol extracts contain antibacterial compounds that effectively inhibited the growth of this bacterium. Moreover, we found that in addition to the ethanol extracts also chloroform, hexane and methanol extracts gave some growth inhibition against $S$. enterica, with inhibition zones up to $18.0 \mathrm{~mm}$. Piperine and piperlongumine showed clear inhibition zones of 14.7 and $11.3 \mathrm{~mm}$ with MIC values of $78 \mu \mathrm{g} / \mathrm{mL}$ and $625 \mu \mathrm{g} / \mathrm{mL}$.

\subsection{UHPLC/QTOF-MS Results}

HPLC-DAD and UHPLC/Q-TOF MS were used for phytochemical profiling of antibacterial extracts of $P$. guineense and for the identification of piperamide alkaloids in Piper guineense. Our HPLC-DAD data indicates that piperamide alkaloids are the predominant compounds in P. guineense hexane, methanol, ethanol and chloroform extracts (Figure 1) and these compounds are suggested to be responsible for the antibacterial effects we have observed for this plant in agreement with other authors [7,34]. For proper identification and characterization of the piperamide alkaloids, a hexane extract of the leaf was chosen. This is because the chromatographic peaks in the hexane extract were more clearly visible and better resolved when compared with the chloroform, methanol and ethanol extracts and moreover, the HPLC-DAD profile of the hexane extract was still found to be very similar to those of the other extracts. In addition, the hexane leaf extract was chosen for phytochemical analysis since we observed large inhibition zones for this extract against most of the bacterial strains, as well as the lowest MIC result of $19 \mu \mathrm{g} / \mathrm{mL}$ against Sarcina sp. Our UHPLC/QTOF-MS result of a leaf hexane extract of P. guineense is presented in Table 4. Altogether 18 compounds were identified, of which the majority were piperamide alkaloids. Among these compounds, the previously known piperamidealkaloids piperine, dihydropiperine, piperylin, dihydropiperylin or piperlonguminine, dihydro-piperlonguminine, wisanine, dihydrowisanine and various derivatives of piperine were identified. These derivatives of piperidinewere identified for the first time in this plant extract (compounds 9, 10b, $\mathbf{1 1}$ and $\mathbf{1 1 b}$ in Table 4). The mass spectrometric data of these compounds were compared to the literature on piperamide alkaloids in Piper species $[15,35,36]$.

In our UHPLC/QTOF-MS runs, positive ion mode was used to get the $\left[\mathrm{M}+\mathrm{Na}^{+}\right.$or $[\mathrm{M}+\mathrm{H}]^{+}$ ions of the expected piperamide alkaloids. Papers on piperamide alkaloids which have been found from Piper spp. were used as references $[15,16,35]$. Among the piperamide alkaloids we have found in the leaves of $P$. guineense, the following could be identified and some of them in high quantities. The exact calculated mass of dihydropiperylin or piperlonguminine (7), Rt UHPLC12.967 min, was deduced to be 273.13648 according to the molecular formula of $\mathrm{C}_{16} \mathrm{H}_{19} \mathrm{NO}_{3}$. The $[\mathrm{M}+\mathrm{Na}]^{+}$ion for dihydropiperylin was 296.1250 and that of piperylin (8) at tR UHPLC 13.567 min was found to be 294.110. Both compounds were present also in the fruit extracts of $P$. guineense. Moreover, piperine (15) at $\mathrm{tR} 44.809 \mathrm{~min}$ (HPLC-DAD), showing a $[\mathrm{M}+\mathrm{Na}]^{+}$ion at $m / z 308.1245$ and dihydropiperine (13) at $\mathrm{tR} 42.215 \mathrm{~min}$ (HPLC-DAD), with a $[\mathrm{M}+\mathrm{Na}]^{+}$ion at $m / z 310.1417$ were present in the leaf extract. To confirm the identity of compound 15 to be piperine, we compared the UV $\lambda$ max-spectrum and the retention time of this compound to a commercial piperine reference compound and the data was found to match. Piperine has been previously reported to be present in in P. guineense extracts of the 
fruits [16]. Wisanine (18) at $\mathrm{tR} 48.429 \mathrm{~min}$ with a $[\mathrm{M}+\mathrm{Na}]^{+}$ion at $m / z 338.1371$ and dihydrowisanine (16) at $\mathrm{tR} 44.848 \mathrm{~min}$ with a $[\mathrm{M}+\mathrm{Na}]^{+}$ion at $\mathrm{m} / z 340.1530$ were also found to be present in the hexane leaf extract. Moreover, some derivatives of piperidine (compounds 9, 10b, 11 and 11b in Table 4) were identified for the first time in this plant extract. Wisanine and dihydrowisanine were present also in the chloroform, ethanol, methanol and hexane extracts according to our HPLC-DAD results. The other alkaloids found in the extracts include: Dihydropiperlonguminine (10) (tR $39.226 \mathrm{~min},[\mathrm{M}+\mathrm{Na}]^{+}$ion at $m / z$ 298.1337); a piperine derivative composed of piperine +1 oxygen- one double bond (10b) ( $t R$ $39.249 \mathrm{~min},[\mathrm{M}+\mathrm{Na}]^{+}$ion at $m / z$ 324.1211); an unknown piperamide alkaloid (11) (tR $40.447 \mathrm{~min}$, $[\mathrm{M}+\mathrm{Na}]^{+}$ion at $m / z$ 358.1528); and a dihydro derivative of piperidine (9) (tR 39,226 min, $[\mathrm{M}+\mathrm{Na}]^{+}$ ion at $m / z$ 326.1374) (Table 4$)$.

\section{Discussion}

In this study, Piper guineense fruit and leaf extracts and piperamide alkaloid compounds have revealed potent antibacterial activity against Gram-positive and Gram-negative bacteria. P. guineense is used by traditional healers in West Africa for various medicinal purposes and often, as herbal remedies for the treatment of symptoms related to bacterial infections, such as diarrhoea, cough and rashes as well as for the treatment of infected wounds and thus these uses are now justified by our results.

In our study, we used Pseudomonas aeruginosa as a Gram-negative model bacterium, since it is capable of causing life-threatening nosocomial infections and many combination therapy resistant strains have been reported [37,38]. In recent times, because of the increase in microbial resistance, only few antibiotics are effective in the treatment of the multidrug-resistant (MDR) and extensively drug-resistant (XDR) lineages of Pseudomonas aeruginosa infections [39]. Our results reveal potent growth inhibitory effects of both leaf and fruit chloroform extracts of $P$. guineense against $P$. aeruginosa, both giving MIC values of $78 \mu \mathrm{g} / \mathrm{mL}$ against this bacterium. This result agrees with Eruteya et al. [26], who also reported that extracts of $P$. guineense fruits give good growth inhibitory activity against P. aeruginosa.

Staphylococcus aureus is becoming increasingly resistant to conventional drug therapies, with MRSA and VRSA strains which are not responding well to any drugs [5]. Previous research has shown that plant-derived compounds and plant extracts could be used as novel treatments and sources of new antibacterial compounds against multi-drug-resistant (MDR) pathogens, including methicillin-resistant Staphylococcus aureus (MRSA) [5]. Our results indicate that alcohol extracts as well as chloroform and n-hexane extracts from the fruits and leaves of P. guineense could be used as good sources for piperamide alkaloids which could be used for treatment of infections caused by $S$. aureus. Interestingly, we found that the extracts were as growth inhibitory as the pure compounds, piperine and piperlonguminine. This suggests that some of the other alkaloids in the extracts could be even more powerful and warrants for further isolation of piperamide alkaloids from P. guineense to test their effects against $S$. aureus.

E. coli is a Gram-negative bacterium that is capable of causing infectious diarrhoea in humans [40]. We found that methanol, ethanol and n-hexane extracts of P. guineense were active against this bacterium. Thus, we recommend that alcohol extracts of $P$. guineense leaves and fruits could be used for the treatment of $E$. coli infections. Our promising resultson the inhibitory capacity of especially ethanol extracts of the fruits of $P$. guineense against $E$. coli would prompt to study the effects of alcohol extracts also against strains of E. coli. Extracts of various polarities, such as methanol, ethanol, chloroform, hexane, cold water macerations and hot water decoctions of the fruits and leaves were screened for antibacterial activity.

We found that piperine and piperlongumine commercial compounds were active against most of the bacteria investigated in our study, with piperlongumine showing the lowest MIC value of $9.7 \mu \mathrm{g} / \mathrm{mL}$ against Sarcina sp. Piperine and piperlongumine showed significant activity against E. coli with MIC values of $19 \mu \mathrm{g} / \mathrm{mL}$ and $39 \mu \mathrm{g} / \mathrm{mL}$, respectively. Piperine has been previously reported to give significant antibacterial activity against some bacterial strains [24,25]. Piperine isolated from 
the fruits of black pepper (Piper nigrum) was found to be effective against Pseudomonas aeruginosa and gave a MIC of $250 \mu \mathrm{g} / \mathrm{mL}$ against this bacterium [41] and this result is in accordance with our MIC of $156 \mu \mathrm{g} / \mathrm{mL}$. At low concentrations of $0.1-10 \mu \mathrm{g} / \mathrm{mL}$, piperine was found to reduce swarming and swimming motility of E. coli [42]. Moreover, piperine was found to be active against $S$. aureus with a MIC of $250 \mu \mathrm{g} / \mathrm{mL}$ and reduced the MIC of mupirocin fourfold and of ciprofloxacin eightfold [43], [44] and was found to inhibit efflux pumps in S. aureus [43].

In our screenings we found that the cold water macerations and hot water decoctions of the fruits and leaves did not show any inhibitory activity against most of the bacteria used for the study. The reason for water extracts lacking antibacterial activity could be attributed to the fact that the bioactive compounds present in the other extracts, which are mostly piperamide alkaloids, are not soluble in water and not even in boiling water according to our HPLC-DAD fingerprints of water extracts. However, in contradiction to our results, there are some reports on the antibacterial effects of water extracts of Piperguineense against Salmonella enterica [33]. The growth inhibitory activity of the water extract in this report might be attributed to the high concentrations used $(20-60 \mathrm{mg} / \mathrm{mL})$ and to some other compounds than piperamide alkaloids, such as phenolic acids. Thus, when P. guineense extracts are to be used for the treatment of bacterial infections in traditional medicine, our result now recommend that oily or ethanol preparations should be used. Our results on the chloroform extracts of $P$. guineense possessing the largest activity against $P$. aeruginosa differs from previous studies stating that methanol extracts of P. guineense are usually the most active ones against this bacterium [26].

From our UHPLC/QTOF-MS analysis conducted on the P. guineense extracts, it could be seen that the extracts were rich in alkaloids and thus their antibacterial activities could be mostly attributed to the presence of numerous piperamides (Table 4, Figure 1). The chemical structures of some of the piperamide compounds identified in this study are shown in Figure 2. Of the piperamides we have found in a hexane leaf extract of $P$. guineense, wisanine, dihydrowisanine, piperine, piperlongumine, 4,5-dihydropiperlonguminine and 4,5-dihydropiperylin have been earlier identified in Piper guineense fruits $[15,16,35]$. In addition to these piperamides we found some new structures, such as a piperine and a piperidine alkaloid derivative (compounds 9 and 10b in Table 4) and two unknown piperamide alkaloids (compounds $\mathbf{1 1}$ and $\mathbf{1 1 b}$ in Table 4). To the best of our knowledge to date there are no piperamides reported in the literature with the same UV $\lambda$ maxima and masses.

\section{Materials and Methods}

\subsection{Plant Material Collection}

The fruits and leaves of P. guineense used in this study were collected from a rural village in Imo State, South Eastern Nigeria. The plant materials were authenticated at the Department of Crop Science of the Federal University of Technology, Owerri, Nigeria. Voucher specimens are deposited in the herbarium of the Department of Crop Science of the same university with the specimen number FUTO/SAAT/NS/005A for the fruit and FUTO/SAAT/NS/005B for the leaf. The reference flora used to identify the species is "Useful Plants of West Tropical Africa." The species commonly occur in South Eastern Nigeria and the geographical coordinates of occurrence of the tested species is $5^{\circ} 45^{\prime} 00^{\prime \prime} \mathrm{N}$, $8^{\circ} 30^{\prime} 00^{\prime \prime} \mathrm{E}$.

\subsection{Extraction}

The air dried plant materials were milled with a grinder to obtain finely ground powdery samples. Sequential extraction was carried out using solvents of varying polarities, starting with the least polar solvent. First, $40 \mathrm{~g}$ of the plant material was extracted with $300 \mathrm{~mL}$ of hexane, followed by extraction with $300 \mathrm{~mL}$ of chloroform, then $300 \mathrm{~mL}$ of ethanol and the residue was finally extracted and washed with $300 \mathrm{~mL}$ of methanol. Seed and leaf plant materials were used for the extractions. For each of the solvents used, the extraction was conducted in duplicates and each extract was filtered using filter paper (Whatman GE Healthcare, Chicago, IL, USA) into a flask of known weight. The filtrate was 
evaporated using a Rotavapor (Heidolph VV2000) combined with a water bath not exceeding $+40{ }^{\circ} \mathrm{C}$, thereafter the extracts were lyophilized for two days to dry completely. The extraction yield for the extractsare as follows: hexane fruit extract $(5.3 \%)$, hexane leaf extract $(1.4 \%)$, chloroform fruit extract $(8.9 \%)$, chloroform leaf extract $(4.7 \%)$, ethanol fruit extract $(8.5 \%)$, ethanol leaf extract $(5.0 \%)$, methanol fruit extract $(10.5 \%)$ and methanol leaf extract $(6.0 \%)$. Macerations and hot water decoctions were also prepared from the plant samples since these preparations are used in traditional medicine. Macerations were prepared by weighing $10 \mathrm{~g}$ of the fruit and leaf plant materials into Erlenmeyer flasks. $100 \mathrm{~mL}$ of water was added and extraction was performed for $24 \mathrm{~h}$ using a magnetic stirrer. The mixture was centrifuged at $2000 \mathrm{rpm}$ for $15 \mathrm{~min}$ (Eppendorf AG centrifuge 5810R, Germany). For the decoctions, $10 \mathrm{~g}$ of the plant material was boiled with $100 \mathrm{~mL}$ of water and allowed to cool. The mixture was centrifuged for $15 \mathrm{~min}$ at $2000 \mathrm{rpm}$ (Eppendorf AG centrifuge 5810R, Hamburg, Germany). Both the macerations and decoctions were carefully filtered using filter paper (Schleicher \& Schuell, $\varnothing=150$ $\mathrm{mm}$, Hamburg, Germany) and freeze dried for two days in a lyophilizer. The extraction yields are as follows: decoction of the seed $(2.8 \%)$, decoction of the leaf extract $(2.4 \%)$, maceration of the seed $(3.0 \%)$ and maceration of the leaf $(2.8 \%)$. Prior to the agar diffusion test, the freeze dried extracts were reconstituted and re-dissolved in their corresponding solvents or in $\mathrm{MeOH}$ to a final concentration of $50 \mathrm{mg} / \mathrm{mL}$ for the antibacterial screening according to the method of Anyanwu and Nwosu [45] and Salih et al. [46].

\subsection{Methods of Analytical Chemistry}

\subsubsection{HPLC-UV/DAD Method}

The liquid chromatographic system consisted of aHPLC Waters $600 \mathrm{E}$ pump and a controller coupled to a 991 photodiode array detector. Samples were injected using an autosampler controlled by Agilent Chemstation software (Waters Corp., Milford, TX, USA). A HypersilRp C18 column was used for the separations (length: $60 \mathrm{~mm}$; internal diameter: $2 \mathrm{~mm}$ ). $5-20 \mu \mathrm{L}$ of the extracts $(5-10 \mathrm{mg} / \mathrm{mL}$ in $100 \% \mathrm{MeOH}$ ) were injected. Gradient runs were performed using two solvent systems: A (aqueous $1.5 \%$ tetrahydrofuran $+0.25 \%$ orthophosphoric acid $)$ and $\mathrm{B}(100 \% \mathrm{MeOH})$. Flow rate was $2 \mathrm{~mL} / \mathrm{min}$. UV fingerprint chromatograms were constructed at 220, 270, 280, 320 and $360 \mathrm{~nm}$. UV $\lambda$ absorption maxima spectra of the major compounds in the P. guineense extract were recorded between 200 and $400 \mathrm{~nm}$ using Agilent Chemstation software. The compounds in the extracts were identified by comparing their retention times and UV $\lambda$ absorption maxima spectra with those of commercial reference standards (piperine and piperlongumine) and previous literatureon HPLC-DAD data for piperamide alkaloids was also used $[15,16]$.

\subsubsection{UHPLC/Q-TOF MS Method}

The masses of piperamide alkaloids in a leaf hexane extract were identified using UHPLC-DAD (Model 1200 Agilent Technologies)-JETSTREAM/QTOFMS (Model 6340 Agilent Technologies) equipped with a $2.1 \times 60 \mathrm{~mm}, 1.7 \mu \mathrm{m} \mathrm{C18}$ column (Agilent technologies) according to Taulavuori et al. [47]. The gradient range was from $0-50 \%$ of solvent A (aqueous $1.5 \%$ tetrahydrofuran $+0.25 \%$ acetic acid) and solvent $\mathrm{B}(100 \%$ methanol $)$ and flow rate $0.4 \mathrm{~mL} / \mathrm{min}$. The qt of mass spectra were acquired at positive ion mode and mass rangefrom $100-2000 \mathrm{~m} / z$ was used.

\subsection{Bacterial Strains}

The bacterial strains used in this investigation were obtained from the Division of Pharmaceutical Biosciences, Faculty of Pharmacy, University of Helsinki, Finland. In all, the growth inhibitory activity of the extracts were investigated using the Gram-positive strains Sarcina sp. FOMK (Division of Pharmaceutical Biosciences, University of Helsinki), Staphylococcus aureus ATCC 25923 and Bacillus cereus ATCC 10987 and the Gram-negative strains Proteus mirabilis 43071, Enterobacter aerogenes 
ATCC13048, Escherichia coli ATCC 25922, Pseudomonas aeruginosa ATCC 27853 and Salmonella enterica ATCC 43845).

\subsubsection{Antibiotics and Pure Compounds}

Tetracycline hydrochloride (Sigma-Aldrich, St. Louis, MO, USA) and rifampicin (Sigma-Aldrich, St. Louis, MO, USA), were used as standard antibiotics for the investigation. Analytical grade piperine and piperlongumine standards ( $\geq 97.0 \%$ purity) purchased from TCI Europe N.V. (Zwijndrecht, Belgium) were used as standard compounds.

\subsubsection{Agar Disk Diffusion Method}

Gram-positive and Gram-negative bacteria representing potential human pathogenic bacteria were used to investigate the in vitro growth inhibitory effects of $P$. guineense extracts. A total of twelve fractions from the fruit and leaf extracts of this plant were tested against eight bacterial strains. An agar disk diffusion method was applied for the initial screening [46]. The freeze dried extracts were re-dissolved in those solvents used originally for their extraction according to the method of Anyanwu and Nwosu [45]. Each of the extracts were prepared to a final concentration of $50 \mathrm{mg} / \mathrm{mL}$ (stock solution). Tetracycline and rifampicin were used as positive controls for the bacterial strains. The antibiotics were dissolved in methanol to a final concentration of $10 \mathrm{mg} / \mathrm{mL}$ used for the test. Sterile petri dishes $(\varnothing=14 \mathrm{~cm}$, VWR Finland) were used for the screenings. For the antibacterial screening, twenty-five $\mathrm{mL}$ of sterile base agar (Antibiotic agar No. 2, Difco, VWR Finland) was applied as a bottom layer into the sterile petri dishes using a sterile, serological pipet (Falcon, Becton Labware Europe) and allowed to solidify. Thereafter twenty-five $\mathrm{mL}$ of isosensitest agar (OXOID, Thermo Fisher Scientific) was applied as the top layer. The petri dishes were all allowed to solidify and then stored at $+4{ }^{\circ} \mathrm{C}$. The screening started with inoculation of the bacteria onto solid nutrient agar slants which were incubated overnight at $+37^{\circ} \mathrm{C}$. The viable bacterial cultures from the agar slants were used to prepare an inoculum for the test. Bacteria from the agar slants were transferred into $2 \mathrm{~mL}$ of $0.9 \%$ $(w / v)$ sodium chloride $(\mathrm{NaCl})$ solution in a sterile glass tube using a sterile inoculation loop. $1 \mathrm{~mL}$ of the suspension was transferred into another sterile glass tube and the absorbance was measured at $625 \mathrm{~nm}$ (UV-Visible Spectrophotometer, Pharmacia LKB-Biochrom 4060). The other $1 \mathrm{~mL}$ of the suspension (sterile part) was diluted with the $0.9 \% \mathrm{NaCl}$ solution so that the absorbance at $\lambda=625 \mathrm{~nm}$ becomes 0.1 (this suspension contains approximately $1.5 \times 10^{8} \mathrm{CFU} / \mathrm{mL}$ ). $200 \mu \mathrm{L}$ of this diluted bacterial suspension was spread evenly on each petri dish and left to dry for some seconds with the lid open. A sterile cork borer (11 $\mathrm{mm}$ in diameter) was used to make six holes equidistantly from each other on the agar surface of the petri dishes. $200 \mu \mathrm{L}$ of the $50 \mathrm{mg} / \mathrm{mL}$ plant extracts and $200 \mu \mathrm{L}$ of the $10 \mathrm{~m} / \mathrm{mL}$ antibiotics were carefully pipette into the holes respectively. Methanol, ethanol, hexane and chloroform, $200 \mu \mathrm{L}$ of each, were used as solvent controls respectively. The petri dishes were transferred to the cold room and incubated at $+4{ }^{\circ} \mathrm{C}$ for $1 \mathrm{~h}$, thereafter they were incubated overnight at $+37^{\circ} \mathrm{C}$. The diameters of the zones of inhibition were measured with a calliper under a petri dish magnifier and expressed as the mean of the diameters of three replicates \pm SEM.

The Activity index (AI) of the various extracts was measured in relation to the standard antibiotic tetracycline according to Fyhrquist et al. [48].

Thus, AI = Inhibition zone of the plant extract/Inhibition zone of standard antibiotic

\subsubsection{Microdilution Method for MIC and MBC Estimation}

From the result obtained from the agar disk diffusion assay, minimum inhibitory concentration (MIC) was estimated for some selected extracts based on their good antibacterial activity. MIC is considered to be the lowest concentration of an extract or compound resulting in the inhibition of at least $90 \%$ of the growth of a bacterial strain. MIC values were determined using a microdilution turbidimetric broth method based on the guidelines of Clinical and Laboratory Standards Institute [49]. Only extracts which expressed remarkable antibacterial activity in the agar plate method were tested 
for MIC. For the MIC evaluation, two-fold serial dilutions of the extracts from $2500-9.75 \mu \mathrm{g} / \mathrm{mL}$ were prepared in sterile Mueller-Hinton broth. Commercial pure compounds, piperine $(1 \mathrm{mg} / \mathrm{mL}$ concentration in methanol) and piperlongumine $(1 \mathrm{mg} / \mathrm{mL}$ concentration in methanol) were also two-fold serially diluted in Mueller -Hinton broth. Tetracycline and rifampicin were each two-fold serially diluted in Mueller-Hinton broth from $125-0.48 \mu \mathrm{g} / \mathrm{mL}$ respectively. 96 well microtiter plates (Nunc, Nunclone, Denmark) were used for the tests. The bacterial cultures were inoculated on Mueller-Hinton agar slants or in $5 \mathrm{~mL}$ Mueller-Hinton broth and grown for $24 \mathrm{~h}$ at $+37^{\circ} \mathrm{C}$ before the test. The turbidity of $1 \mathrm{~mL}$ of the overnight bacterial culture was measured at $625 \mathrm{~nm}$ using a UV-Visible Spectrophotometer type 1510 (Thermo Fisher Scientific Oy). The absorbance was adjusted to 0.1 at $625 \mathrm{~nm}$ (approximately $1.0 \times 10^{8} \mathrm{CFU} / \mathrm{mL}$ ). $100 \mu \mathrm{L}$ of this suspension $\mathrm{A}_{625}=0.1$ was further diluted 100-fold to get a working suspension or inoculum containing approximately $1.0 \times 10^{6} \mathrm{CFU} / \mathrm{mL}$. $100 \mu \mathrm{L}$ of this inoculum and $100 \mu \mathrm{L}$ of the plant extracts, pure compounds, antibiotics and solvent controls, were introduced into the 96 well microtiter plates. Therefore, each well contained $5 \times 10^{5}$ $\mathrm{CFU} / \mathrm{mL}$. The solvent controls contained a maximum of $5 \%(v / v)$ of each solvent to be tested for toxicity. The growth control (GC wells) contained only the bacterial suspension and the test wells ( $\mathrm{T}$ wells) contained plant extracts or pure compounds + bacterial suspension. Moreover, negative control wells were prepared for each plant extract/compound to be tested and these wells contained plant extract/pure compound and the broth only in order to subtract the light absorbance of extracts and compounds from the wells containing the corresponding extracts/compounds with bacteria. The microwell plates were incubated for $24 \mathrm{~h}$ in an incubator coupled to a shaker at $+37^{\circ} \mathrm{C}$. The turbidity of the wells at $620 \mathrm{~nm}$ was recorded using a Victor 1420 spectrophotometer (Wallac, Finland). The MIC values were considered as the lowest concentration of each tested extract/compound or antibiotic which resulted in a $90 \%$ or more inhibition of the growth control. The tests were done in triplicate and the $\%$ growth was expressed as the mean of these triplicates \pm standard error of mean (SEM). The minimum bactericidal concentration (MBC) was evaluated by pipetting $100 \mu \mathrm{L}$ from those wells of the microtiter plate, which contained 2 and 4 times higher concentrations than the MIC values on petri dishes $(\varnothing=9 \mathrm{~cm})$ containing Mueller-Hinton agar, where after, the dishes were incubated for $24 \mathrm{~h}$ at $+37^{\circ} \mathrm{C}$. The MBC was taken as the lowest concentration where no visible growth on the petri dish was observed after the incubation.

\section{Conclusions}

The present study demonstrated that extracts of P. guineense, enriched in alkaloids, have potent antibacterial activity against a panel of Gram-positive and Gram-negative bacteria, including significant human pathogens. It has been established through this study that alkaloids are the main antibacterial compounds present in P. guineense leaves and fruits. However, water extracts and decoctions, which are frequently used as traditional medicinal preparations, were devoid of these alkaloids even at the highest tested concentration of $50 \mathrm{mg} / \mathrm{mL}$ and thus inactive against the studied bacteria. Our results revealed that $P$. guineense alcohol, chloroform and hexane extracts from the leaves and fruits are richsources of piperamide compounds which could help to combat bacterial infections. Thus our results encourage especially the use of alcohol extracts of $P$. guineense leaves and fruits in traditional medicine.

Our results warrant further in depth research on the antibacterial mechanisms of action of piperamide compounds, since this is not thoroughly studied. Plant derived compounds with new mechanisms of action could be used for the treatment of multi-drug resistant bacteria and P. guineense as well as other species of Piper could be sources for some of these compounds. Moreover, the alkaloids in P. guineense could be investigated for their anti-biofilm activities, including quorum sensing. The inhibitory activity observed with the various fractions and extracts against the tested bacteria in this investigation, warrants further exploration of the bioactive compounds from P. guineense as molecular scaffolds for new therapeutic agents in modern antimicrobial therapy, as well as on their potential as adjuvants together with conventional antibiotics to restore or to increase the effects of the antibiotics in current use. The possibility to use piperamide alkaloids from P. guineense (and other 
Piper spp.) for the treatment of drug resistant strains of Pseudomonas aeruginosa, Staphylococcus aureus, Bacillus cereus and Salmonella enterica should be explored.

Author Contributions: E.E.M., P.F. and Y.H. planned and designed the experiments. E.E.M. performed the sample collection and extraction under the supervision of Y.H. and P.F. E.E.M. and P.F. conducted the invitro antibacterial screening and MIC estimations. R.J.-T. and P.F. performed the HPLC-DAD and UHPLC/Q-TOF MS analysis. The manuscript was first drafted by E.E.M. and Y.H. The manuscript was further revised and corrected by P.F., R.J.-T. and H.V. All the author shave read and approved the final version of the manuscript.

Funding: This research was funded by grant 2017-7 from the Ekhaga Foundation, Sweden and Academy of Finland, grant number 267360 .

Acknowledgments: The authors are grateful to the Faculty of Pharmacy, Division of Pharmaceutical Biosciences, University of Helsinki and Natural Product Research Laboratory, Department of Environmental and Biological Sciences, University of Eastern Finland, Joensuu for supporting this work. The first and second authors acknowledge the financial support from the Ekhaga Foundation, Sweden and Academy of Finland.

Conflicts of Interest: The authors declare no conflict of interest. The funders had no role in the design of the study; in the collection, analyses, or interpretation of data; in the writing of the manuscript, or in the decision to publish the results.

\section{References}

1. Mulholland, E.K.; Adegbola, R.A. Bacterial infections-A major cause of death among children in Africa. N. Engl. J. Med. 2005, 352, 75-77. [CrossRef] [PubMed]

2. Palaniappan, K.; Holley, R.A. Use of natural antimicrobials to increase antibiotic susceptibility of drug resistant bacteria. Int. J. Food Microbiol. 2010, 140, 164-168. [CrossRef] [PubMed]

3. Irshad, S.; Ashfaq, A.; Muazzam, A.; Yasmeen, A. Antimicrobial and anti-prostate cancer activity of turmeric (Curcuma longa L.) and black pepper (Piper nigrum L.) used in typical Pakistani cuisine. Pak. J. Zool. 2017, 49, 5. [CrossRef]

4. Alviano, D.; Alviano, C. Plant extracts: Search for new alternatives to treat microbial diseases. Curr. Pharm. Biotechnol. 2009, 10, 106-121. [CrossRef] [PubMed]

5. Subramani, R.; Narayanasamy, M.; Feussner, K. Plant-derived antimicrobials to fight against multi-drug-resistant human pathogens. 3 Biotech 2017, 7, 172. [CrossRef] [PubMed]

6. Agyare, C.; Spiegler, V.; Asase, A.; Schulz, M.; Hempel, G.; Hensel, A. An ethnopharmacological survey of medicinal plants traditionally used for cancer treatment in the Ashanti region, Ghana. J. Ethnopharmacol. 2018, 212, 137-152. [CrossRef] [PubMed]

7. Besong, E.E.; Balogun, M.E.; Djobissie, S.F.; Mbamalu, O.S.; Obimma, J.N. A review of Piper guineense (African Black Pepper). Int. J. Pharm. Pharm. Res. 2016, 6, 368-384.

8. Mgbeahuruike, E.E.; Yrjönen, T.; Vuorela, H.; Holm, Y. Bioactive compounds from medicinal plants: Focus on Piper species. S. Afr. J. Bot. 2017, 112, 54-69. [CrossRef]

9. Mgbeahuruike, E.E.; Vuorela, H.; Yrjonen, T.; Holm, Y. Optimization of thin-layer chromatography and high-performance liquid chromatographic method for Piper guineense extracts. Nat. Prod. Commun. 2018, 13, $25-28$.

10. Abila, B.; Richens, A.; Davies, J. Anticonvulsant effects of extracts of the West African black pepper, Piper guineense. J. Ethnopharmacol. 1993, 39, 113-117. [CrossRef]

11. Freiesleben, S.H.; Soelberg, J.; Jäger, A.K. Medicinal plants used as excipients in the history in Ghanaian herbal medicine. J. Ethnopharmacol. 2015, 174, 561-568. [CrossRef] [PubMed]

12. Ene-Obong, H.; Onuoha, N.; Aburime, L.; Mbah, O. Chemical composition and antioxidant activities of some indigenous spices consumed in Nigeria. Food Chem. 2018, 238, 58-64. [CrossRef] [PubMed]

13. Ajibesin, K.; Bala, D.N.; Umoh, U.F. The use of medicinal plants to treat sexually transmitted diseases in Nigeria: Ethnomedicinal survey of Niger Delta Region. Int. J. Green Pharm. 2011, 5, 3. [CrossRef]

14. Parmar, V.S.; Jain, S.C.; Bisht, K.S.; Jain, R.; Taneja, P.; Jha, A.; Tyagi, O.D.; Prasad, A.K.; Wengel, J.; Olsen, C.E. Phytochemistry of the genus Piper. Phytochemistry 1997, 46, 597-673. [CrossRef]

15. Adesina, S.K.; Adebayo, A.S.; Adesina, S.K.; Groning, R. New constituents of Piper guineense fruit and leaf. Pharmazie 2003, 58, 423-425. [CrossRef] [PubMed] 
16. Scott, I.M.; Puniani, E.; Jensen, H.; Livesey, J.F.; Poveda, L.; Sánchez-Vindas, P.; Durst, T.; Arnason, J.T. Analysis of Piperaceae germplasm by HPLC and LCMS: A method for isolating and identifying unsaturated amides from Piper spp extracts. J. Agric. Food Chem. 2005, 53, 1907-1913. [CrossRef] [PubMed]

17. Umadevi, P.; Deepti, K.; Venugopal, D.V. Synthesis, anticancer and antibacterial activities of piperine analogs. Med. Chem. Res. 2013, 22, 5466-5471. [CrossRef]

18. Balouiri, M.; Sadiki, M.; Ibnsouda, S.K. Methods for in vitro evaluating antimicrobial activity: A review. J. Pharm. Anal. 2016, 6, 71-79. [CrossRef] [PubMed]

19. Dada, A.A.; Ifesan, B.O.T.; Fashakin, J.F. Antimicrobial and antioxidant properties of selected local spices used in "Kunun" beverage in Nigeria. Acta Sci. Pol. Technol. Aliment. 2013, 12, 373-378.

20. Omonigbehin, E.A.; Deji-Agboola, M.A.; Ezeh, A.R.; Smitha, S.I.; Bamidele, M.; Fesobi, T.W.; Adenike, F.M.; Kayode, A.S.; Oluwadun, A. Piper guineense: Apossible alternative treatment for multidrug resistant EHEC. Int. J. Appl. Sci. Technol. 2013, 3, 2.

21. Ebana, R.; Edet, U.; Ekanemesang, U.; Ikon, G.; Etok, C.; Edet, A. Antimicrobial activity, phytochemical screening and nutrient analysis of Tetrapleura tetraptera and Piper guineense. Asian J. Med. Health 2016, 1, 1-8. [CrossRef]

22. Tekwu, E.M.; Askun, T.; Kuete, V.; Nkengfack, A.E.; Nyasse, B.; Etoa, F.; Beng, V.P. Antibacterial activity of selected Cameroonian dietary spices ethno-medically used against strains of Mycobacterium tuberculosis. J. Ethnopharmacol. 2012, 142, 374-382. [CrossRef] [PubMed]

23. Konning, G.; Agyare, C.; Ennison, B. Antimicrobial activity of some medicinal plants from Ghana. Fitoterapia 2004, 75, 65-67. [CrossRef] [PubMed]

24. Chavarria, D.; Silva, T.; Magalhães e Silva, D.; Remião, F.; Borges, F. Lessons from black pepper: Piperine and derivatives thereof. Expert Opin. Ther. Pat. 2016, 26, 245-264. [CrossRef] [PubMed]

25. Philipova, I.; Valcheva, V.; Mihaylova, R.; Mateeva, M.; Doytchinova, I.; Stavrakov, G. Synthetic piperine amide analogs with antimycobacterial activity. Chem. Biol. Drug Des. 2018, 91, 763-768. [CrossRef] [PubMed]

26. Eruteya, O.; Ire, F.; Aneke, C. Evaluation of the Extracts of Piper guineense for Antibacterial activity against spoilage bacteria of Rivers State 'Native'Soup. J. Environ. Sci. Toxicol. Food Technol. 2017, 11, 68-73.

27. Naika, R.; Prasanna, K.; Ganapathy, P.S. Antibacterial activity of piperlongumine an alkaloid isolated from methanolic root extract of Piper Longum L. Pharmacophore 2010, 1, 141-148.

28. Laass, M.W.; Pargac, N.; Fischer, R.; Bernhardt, H.; Knoke, M.; Henker, J. Emphyseamtic gastritis caused by Sarcina ventriculi. Gastrointest. Endosc. 2010, 72, 1101-1103. [CrossRef] [PubMed]

29. Lam-Himlin, D.; Tsiatis, A.C.; Montgomery, E.; Pai, R.K.; Brown, J.A.; Razavi, M.; Lamps, L.; Eshleman, J.R.; Bhagavan, B.; Anders, R.A. Sarcina organisms in the gastrointestinal tract: A clinicopathologic and molecular study. Am. J. Surg. Pathol. 2011, 35, 1700-1705. [CrossRef] [PubMed]

30. De Meij, T.G.; Van Wijk, M.P.; Mookhoek, A.; Budding, A.E. Ulcerative Gastritis and esophagitis in two Children with Sarcina ventriculi Infection. Front. Med. 2017, 4, 145. [CrossRef] [PubMed]

31. Okeke, M.; Iroegbu, C.; Jideofor, C.; Okoli, A.; Esimone, C. Anti-microbial activity of ethanol extracts of two indigenous Nigerian spices. J. Herbs Spices Med. Plants 2001, 8, 39-46. [CrossRef]

32. Jha, P.; Kim, C.; Kim, D.; Chung, J.; Yoon, N.; Jha, B.; Kim, S.W.; Jang, S.J.; Ahn, Y.; Chung, J.K. Transmission of Enterobacter aerogenes septicemia in healthcare workers. SpringerPlus 2016, 5, 1397. [CrossRef] [PubMed]

33. Temitope, O.O. Comparative study of antibacterial and phytochemical properties of nigerian medicinal plants on salmonella bongori and salmonella enteritidis isolated from poultry feaces in owo local government. Ondo State, Nigeria. J. Arch. Curr. Res. Int. 2015, 2, 1-11. [CrossRef]

34. Juliani, H.R.; Koroch, A.; Giordano, L.; Amekuse, L.; Koffa, S.; Asante-Dartey, J.; Simon, J. Piper guineense (Piperaceae): Chemistry, traditional uses and functional properties of West African black pepper. In African Natural Plant Products Volume II: Discoveries and Challenges in Chemistry, Health and Nutrition; ACS Publications: Edison, NJ, USA, 2013; pp. 33-48.

35. Kotte, S.C.B.; Dubey, P.; Murali, P. Identification and characterization of stress degradation products of piperine and profiling of a black pepper (Piper nigrum L.) extract using LC/Q-TOF-dual ESI-MS. Anal. Methods 2014, 6, 8022-8029.

36. Liu, H.; Luo, R.; Chen, X.; Ba, Y.; Zheng, L.; Guo, W.; Wu, X. Identification and simultaneous quantification of five alkaloids in Piper longum L. by HPLC-ESI-MS and UFLC-ESI-MS/MS and their application to Piper nigrum L. Food Chem. 2015, 177, 191-196. [CrossRef] [PubMed] 
37. Lister, P.D.; Wolter, D.J.; Hanson, N.D. Antibacterial-resistant Pseudomonas aeruginosa: Clinical impact and complex regulation of chromosomally encoded resistance mechanisms. Clin. Microbiol. Rev. 2009, 22, 582-610. [CrossRef] [PubMed]

38. Rasamiravaka, T.; Labtani, Q.; Duez, P.; El Jaziri, M. The formation of biofilms by Pseudomonas aeruginosa: A review of the natural and synthetic compounds interfering with control mechanisms. BioMed Res. Int. 2015, 2015, 759348. [CrossRef] [PubMed]

39. Kaiser, S.J.; Mutters, N.T.; Blessing, B.; Günther, F. Natural isothiocyanates express antimicrobial activity against developing and mature biofilms of Pseudomonas aeruginosa. Fitoterapia 2017, 119, 57-63. [CrossRef] [PubMed]

40. Mirhoseini, A.; Amani, J.; Nazarian, S. Review on pathogenicity mechanism of enterotoxigenic Escherichia coli and vaccines against it. Microb. Pathog. 2018, 117, 162-169. [CrossRef] [PubMed]

41. Karsha, P.V.; Lakshmi, O.B. Antibacterial activity of black pepper (Piper nigrum Linn.) with special reference to its mode of action on bacteria. Ind. J. Nat. Prod. Res. 2010, 1, 213-215.

42. Dusane, D.H.; Hosseinidoust, Z.; Asadishad, B.; Tufenkji, N. Alkaloids modulate motility, biofilm formation and antibiotic susceptibility of uropathogenic Escherichia coli. PLoS ONE 2014, 9, e112093. [CrossRef] [PubMed]

43. Mirza, Z.M.; Kumar, A.; Kalia, N.P.; Zargar, A.; Khan, I.A. Piperine as an inhibitor of the MdeA efflux pump of Staphylococcus aureus. J. Med. Microbiol. 2011, 60, 1472-1478. [CrossRef] [PubMed]

44. Stavri, M.; Piddock, L.J.; Gibbons, S. Bacterial efflux pump inhibitors from natural sources. J. Antimicrob. Chemother. 2006, 59, 1247-1260. [CrossRef] [PubMed]

45. Anyanwu, C.; Nwosu, G. Assessment of the antimicrobial activity of aqueous and ethanolic extracts of Piper guineense leaves. J. Med. Plants Res. 2014, 8, 436-440. [CrossRef]

46. Salih, E.; Kanninen, M.; Sipi, M.; Luukkanen, O.; Hiltunen, R.; Vuorela, H.; Julkunen-Tiitto, R.; Fyhrquist, P. Tannins, flavonoids and stilbenes in extracts of African savanna woodland trees Terminalia brownii, Terminalia laxiflora and Anogeissus leiocarpus showing promising antibacterial potential. S. Afr. J. Bot. 2017, 108, 370-386. [CrossRef]

47. Taulavuori, K.; Julkunen-Tiitto, R.; Hyöky, V.; Taulavuori, E. Blue mood for superfood. Nat. Prod. Commun. 2013, 8, 791-794.

48. Fyhrquist, P.; Laakso, I.; Marco, S.G.; Julkunen-Tiitto, R.; Hiltunen, R. Antimycobacterial activity of ellagitannin and ellagic acid derivate rich crude extracts and fractions of five selected species of Terminalia used for treatment of infectious diseases in African traditional medicine. S. Afr. J. Bot. 2014, 90, 1-16. [CrossRef]

49. Cockerill, F.R.; Wikler, M.; Bush, K.; Dudley, M.; Eliopoulos, G.; Hardy, D. Performance Standards for Antimicrobial Susceptibility Testing: Twenty-Second Informational Supplement; Clinical and Laboratory Standards Institute: Wayne, PA, USA, 2012. 